\title{
ANALISIS RETURN ON EQUITY, PRICE EARNING RATIO DAN TOTAL ASSET TURNOVER DALAM MEMPREDIKSI PERUBAHAN LABA PERBANKAN
}

\author{
Pratiwi Rosa Damayanti ${ }^{1)}$, Herman Sjahruddin ${ }^{2)}$, Muh.Irfai Sohilauw ${ }^{3)}$ \\ ${ }^{1,2,3)}$ Sekolah Tinggi Ilmu Ekonomi Makassar Bongaya, Sulawesi Selatan \\ Penulis Koresponden : pratiwirosa230@ gmail.com ${ }^{1)}$
}

\begin{abstract}
Abstrak
Penelitian ini bertujuan untuk menguji dan menganalisis efek rasio keuangan (return on equity, price earning ratio dan total asset turnover) dalam memprediksi perubahan laba di masa yang akan datang perbankan. Populasi dalam penelitian ini yaitu seluruh laporan keuangan PT. Bank BNI (Persero) Tbk periode 2009-2018 dilihat dari per triwulan. Jumlah tahun pengamatan dalam penelitian ini dilakukan selama 10 tahun pengamatan, sehingga jumlah observasi adalah 10 tahun $\mathrm{x} 4$ triwulan $=40$ sampel pengamatan. Alat analisis yang digunakan adalah analisis regresi linier berganda dengan menggunakan Statistical Package for the Social Sciences Vers. 25. Hasil penelitian menunjukkan bukti bahwa hanya total asset turnover yang menghasilkan efek negatif dan signifikan, sementara return on equity, price earning ratio hanya mampu menghasilkan efek positif namun tidak signifikan dalam memprediksi perubahan laba di masa yang akan datang
\end{abstract}

Keywords: Return On Equity, Price Earning Ratio, Total Asset Turnover dan Perubahan Laba. 


\section{PENDAHULUAN}

PT. Bank BNI (Persero), Tbk merupakan salah satu bank umum milik pemerintah yang telah terdaftar (listing) di Bursa Efek Indonesia. Dalam menjalankan aktivitas bisnisnya, perbankan dapat bertahan atau bahkan dapat menjalankan aktivitasnya apabila didorong dengan laba perusahaan. Laba sering digunakan sebagai dasar untuk mengukur pengembalian investasi maupun penghasilan per lembar saham (earning per share). Selain itu, laba merupakan pengukuran atas perubahan kekayaan pemegang saham (perubahan nilai) maupun merupakan estimasi laba masa depan (Wild et al, 2015: 408).

Perolehan laba perbankan dipengaruhi oleh aktivitas keuangan bank, dalam kegiatan usahanya yang menghimpun dana dari masyarakat dalam bentuk tabungan, deposito dan menyalurkan kredit dan jasa-jasa dalam lalu lintas pembayaran serta peredaran uang, telah mengalami perkembangan dalam mencapai perubahan laba di setiap tahunnya, dalam menganalisis aktivitas-aktivitas tersebut, pihak manajemen perusahaan menggunakan rasio keuangan (Pangerapan dkk, 2017).

Rasio keuangan adalah angka yang diperoleh dari hasil perbandingan dari satu pos laporan keuangan dengan pos lainnya yang mempunyai hubungan yang relevan dan signifikan. Rasio menggambarkan suatu hubungan atau penimbangan antara suatu jumlah tertentu dengan jumlah yang lain, dan dengan menggunakan alat analisa berupa rasio ini akan dapat menjelaskan atau memberi gambaran kepada penganalisa tentang baik atau buruknya keadaan atau posisi keuangan suatu perusahaan. Rasio keuangan meliputi beberapa variabel antara lain Current Ratio, Debt to Equity Ratio, Return on equity, Total Assets Turn Over Ratio, Price earning ratio dan Net Profit Margin (Manurung, C. S., dan Silalahi, E. R., 2016; Lorenza, dkk., 2020).

Penelitian terdahulu membuktikan bahwa ROE berpengaruh negatif dan signifikan terhadap perubahan laba (Ghazali dan Martunis 2013:25). Namun, hasil berbeda ditunjukkan peneliti lainnya bahwa ROE berpengaruh positif dan signifikan terhadap perubahan laba (Suprihatmi dan Wahyudin 2003).

Rasio keuangan lainnya yang mempengaruhi perubahan laba adalah Price earning ratio $(P E R)$, Penelitian terdahulu membuktikan bahwa PER berpengaruh positif dan signifikan
(Sri Lestari, 2014). Namun hasil berbeda ditunjukkan peneliti lainnya bahwa PER negatif dan tidak signifikan (Nur Amalina, dkk., 2014). Perubahan laba perusahaan dapat dianalisis melalui Total Assets Turn Over (TATO). Penelitian terdahulu membuktikan bahwa TATO berpengaruh positif dan signifikan terhadap perubahan laba (Syamsuddin dan Primayuta 2009). Namun, hasil berbeda ditunjukkan peneliti lainnya, bahwa TATO berpengaruh negatif dan tidak signifikan terhadap perubahan laba (Sari, 2007).

Tinggi atau rendahnya perubahan laba perusahaan dalam pandangan teori sinyal (signaling theory) merupakan suatu tindakan yang diambil oleh manajemen dengan memberikan informasi kepada para investor berhubungan dengan cara pandang manajemen terhadap prospek/harapan perusahaan ke depannya (Ifada, L. M., dan Puspitasari, T., 2016; Harris, dkk., 2020). Pengumuman laba memuat informasi yang dipakai para investor untuk membuat keputusan pada kegiatan investasi serta memproyeksikan atau memperkirakan prospek/harapan perusahaan di masa yang akan datang. Apabila pihak manajemen bank mengumumkan terjadinya peningkatan laba, maka investor akan menerima informasi bahwa kondisi keuangan perusahaan relatif baik di masa yang akan dating, namun jika pihak manajemen mengumumkan laba yang turun/rendah, investor akan menerima informasi bahwa kondisi keuangan perusahaan relatif tidak baik di masa yang akan datang (Ifada, L. M., dan Puspitasari, T., 2016).

Penelusuran pada laba perusahaan dengan menggunakan laporan keuangan menunjukkan terjadinya peningkatan laba pada PT. Bank BNI (Persero), Tbk pada tahun 2017 - 2018, yang dapat dilihat pada tabel berikut:

Tabel 1

Laba PT. Bank BNI (Persero), Tbk Tahun 2017 -2018 (dalam Rupiah)

\begin{tabular}{crrr}
\hline \multirow{2}{*}{ Triw } & \multicolumn{2}{c}{ Laba } & \\
\cline { 2 - 3 } ulan & \multicolumn{1}{c}{2017} & \multicolumn{1}{c}{2018} & \\
\hline & 3.145 .592 .0 & 3.512 .821 .0 & 367.229 .00 \\
TR-1 & 00.000 & 00.000 & 0.000 \\
& 6.223 .596 .0 & 7.170 .925 .0 & 947.329 .00 \\
TR-2 & 00.000 & 00.000 & 0.000 \\
& 9.789 .447 .0 & 11.088 .719$. & 1.299 .272$. \\
TR-3 & 00.000 & 000.000 & 000.000 \\
& 13.045 .845$. & 14.462 .162$. & 1.416 .317$. \\
TR-4 & 000.000 & 000.000 & 000.000 \\
\hline
\end{tabular}




\begin{tabular}{crrr}
\hline Rata- & 8.051 .120 .0 & 9.058 .656 .7 & 1.007 .536$. \\
rata & 00.000 & 50.000 & 750.000 \\
\hline
\end{tabular}

Sumber: PT. Bank BNI (Persero) Tbk

(https://www.bni.co.id/id-id/, 2020).

Berdasarkan hasil survei dapat dikemukakan bahwa laba PT. Bank BNI (Persero), Tbk Tahun 2017 - 2018 mengalami peningkatan terbukti pada triwulan I tahun 2017 laba yang diperoleh PT. Bank Negara Indonesia (Persero) Tbk sebesar Rp.3.145.592.000.000,- mengalami peningkatan pada triwulan I tahun 2018 menjadi sebesar Rp.3.512.821.000.000,- atau perubahannya menjadi sebesar Rp.367.229.000.000,-. Pada triwulan II tahun 2017 laba yang diperoleh sebesar Rp.6.223.596.000.000,- mengalami peningkatan pada Triwulan II tahun 2018 menjadi sebesar Rp.7.170.925.000.000,- atau perubahannya menjadi sebesar Rp. 947.329.000.000,-.

Pada Triwulan III tahun 2017 laba yang diperoleh sebesar Rp.9.789.447.000.000,mengalami peningkatan pada Triwulan III tahun 2018 menjadi sebesar Rp.11.088.719.000.000,- atau perubahannya menjadi sebesar Rp.1.299.272.000.000,-. Pada Triwulan IV tahun 2017 laba yang diperoleh PT. Bank BNI (Persero) Tbk sebesar Rp.13.045.845.000.000,- mengalami peningkatan pada Triwulan IV tahun 2018 menjadi sebesar Rp.14.462.162.000.000,- atau perubahannya menjadi sebesar Rp.1.416.317.000.000,-.

Mengacu pada penerimaan laba bank tersebut dan perbedaan temuan dari para peneliti terdahulu serta teori signal yang telah dikemukakan, maka penelitian ini dilakukan dengan judul "Analisis Rasio Keuangan Dalam Memprediksi Perubahan Laba di Masa Yang Akan Datang pada PT. Bank BNI (Persero) Tbk".

Penelitan ini bertujuan untuk menguji: (1) pengaruh return on equity dalam memprediksi perubahan laba di masa yang akan datang pada PT. Bank BNI (Persero) Tbk. (2) pengaruh price earning ratio dalam memprediksi perubahan laba di masa yang akan datang pada PT. Bank BNI (Persero) Tbk. (3) pengaruh total asset turnover dalam memprediksi perubahan laba di masa yang akan datang pada PT. Bank BNI (Persero) Tbk. (4) Variabel yang dominan terhadap perubahan laba di masa yang akan datang pada PT. Bank BNI (Persero) Tbk.

\section{TINJAUAN PUSTAKA}

Return on equity (ROE)

ROE merupakan salah satu rasio keuangan yang sering digunakan oleh investor untuk menganalisis laba perusahaan. Pengaruh rasio return on equity terhadap perubahan laba bersih perusahaan menjelaskan bahwa semakin tinggi ROE maka semakin tinggi tingkat laba yang dihasilkan karena penambahan modal kerja dapat digunakan untuk membiayai operasi perusahaan yang akhirnya dapat menghasilkan laba (Suwarno, 2004).

\section{Price earning ratio (PER)}

Rasio ini biasanya digunakan investor untuk memprediksi kemampuan perusahaan dalam menghasilkan laba dimasa yang akan datang. Perusahaan dengan peluang pertumbuhan tinggi biasanya mempunyai PER yang tinggi pula, dan hal ini menunjukkan bahwa pasar mengharapkan pertumbuhan laba di masa mendatang. Sebaliknya, perusahaan dengan tingkat pertumbuhan rendah cenderung mempunyai PER yang rendah pula. PER menggambarkan apresiasi pasar terhadap kemampuan perusahaan dalam menghasilkan laba (Amalina, 2013).

\section{Total Assets Turn Over (TATO)}

Merupakan perbandingan antara total penjualan yang dihasilkan terhadap total aktiva / aset yang dimiliki perusahaan. Sehingga semakin besar TATO menjelaskan semakin efisien atau berdaya gunanya aktiva dan aset perusahaan dalam memperolah penjualan (Ifada dan Puspitasari, 2016).

\section{Laba}

Salah satu komponen dalam laporan keuangan adalah informasi laba yang bertujuan untuk menilai kinerja dalam perusahaan, membantu mengestimasi kemampuan laba yang representatif dalam jangka panjang dan menaksir risiko dalam investasi atau meminjamkan dana karena investor memiliki kecenderungan bereaksi terhadap segala informasi yang berhubungan dengan perusahaan yang mempengaruhi nilai investasi mereka di perusahaan tersebut (Dwiatmini dan Nurkholis, 2011). Laba memiliki potensi informasi yang sangat penting bagi pihak eksternal maupun internal. Laba sering digunakan sebagai dasar untuk mengukur 
pengembalian investasi maupun penghasilan per lembar saham (earning per share) (Dwiatmini dan Nurkholis, 2011).

\section{METODE PENELITIAN}

Penelitian ini menggunakan pendekatan kuantitatif yaitu menggunakan cara berpikir deduktif yang menunjukkan bahwa pemikiran dalam penelitian ini didasarkan pada pola yang umum atau universal kemudian mengarah kepada pola yang lebih sempit atau spesifik. Sedangkan berdasarkan tingkat eksplanasinya, penelitian ini tergolong penelitian asosiatif. Penelitian asosiatif adalah penelitian yang bertujuan untuk mengetahui pengaruh atau hubungan sebab akibat, yaitu variabel bebas atau independen $(\mathrm{X})$ terhadap variabel terikat atau dependen (Y) (Prawiroharjo Thauwrisan,

\begin{tabular}{|c|c|}
\hline Pengamatan & $\begin{array}{c}\text { Unstandardized } \\
\text { Residual } \\
\end{array}$ \\
\hline Jumlah data & 40 \\
\hline Test Statistic & .117 \\
\hline Asymp. Sig. (2-tailed) & $.175^{\mathrm{c}}$ \\
\hline
\end{tabular}

Populasi dalam penelitian ini yaitu seluruh laporan keuangan PT. Bank BNI (Persero) Tbk periode 2009-2018 dilihat dari per triwulan. Sehingga jumlah tahun pengamatan dalam penelitian ini dilakukan selama 10 tahun pengamatan, sehingga jumlah observasi adalah 10 tahun $\mathrm{x} 4$ triwulan $=40$ sampel pengamatan .

Penelitian menggunakan bentuk pengumpulan data atau desain cross-sectional, yang merupakan suatu jenis penelitian yang dilakukan dengan cara mengumpulkan data pada satu waktu yang sama selama satu periode hari, minggu atau bulan maupun tahun (Susanto, 2013:67). Dengan jenis data yang digunakan adalah jenis data kuantitatif. Data yang dimaksud dalam penelitian ini adalah Return On Equity, Price Earning Ratio, Total Assets Turn Over, dan Perubahan Laba. Sumber data dalam penelitian ini adalah data sekunder yang diperoleh dari lembaga atau instansi yang berhubungan dengan objek penelitian dan didapatkan melalui dokumen-dokumen, yaitu data dari Laporan Keuangan Publikasi pada periode tahun 2009-2018 yang diterbitkan oleh Bursa Efek Indonesia. Teknik pengumpulan data yang digunakan adalah teknik dokumentasi, yaitu teknik yang dilakukan dengan cara mengumpulkan, mencatat, dan mengkaji data sekunder yang berupa data laporan keuangan PT. Bank BNI (persero), Tbk yang terdaftar di Bursa Efek Indonesia melalui www.idx.co.id.

\section{HASIL DAN PEMBAHASAN}

\section{Uji Asumsi Klasik}

Uji Normalitas adalah untuk untuk menguji apakah dalam model regresi variabel independen dan variabel dependen memiliki distribusi data normal atau tidak (Ghozali, 2016:154). Model regresi yang baik adalah memiliki distribusi normal atau mendekati normal. Uji normalitas data dapat dilakukan dengan menggunakan One Sample Kolmogorov- Smirnov yaitu dengan ketentuan apabila nilai signifikan diatas 0,05, maka data terdistribusi normal. Sedangkan, jika hasil One Sample Kolmogorov-Smirnov menunjukkan nilai signifikan dibawah 0,05 , maka data tidak terdistribusi normal.

\section{Tabel 2. Hasil Uji Normalitas}

Berdasarkan data pada Tabel 2., dapat diketahui bahwa nilai test statistic sebesar $0.117>0.05$ dan nilai Kolmogorov-Smirnov (KS) sebesar $0.175>0.05$, maka dapat dinyatakan bahwa data yang diuji berdistribusi normal.

Uji Autokorelasi bertujuan menguji apakah dalam model regresi linear ada korelasi antara kesalahan pengganggu pada periode $t$ dengan kesalahan pengganggu pada periode $\mathrm{t}-1$ (sebelumnya) (Ghozali, $2016: 155$ ).

Hasil uji autokorelasi pada model summary menunjukkan bahwa nilai Durbin-Watson sebesar 1.936, pembanding menggunakan nilai signifikan 5\% (0.05). Jumlah sampel sebanyak 40 (n) dan jumlah variabel independen $3(\mathrm{k}=3)$, maka pada tabel Durbin-Watson akan diperoleh nilai dL sebesar 1.3384, nilai dU sebesar 1.6589. Karena nilai Durbin-Watson 1.936 berada diluar dari daerah antara nilai $\mathrm{dL}$ dan nilai $\mathrm{dU}$ atau $\mathrm{dL}<\mathrm{d}<\mathrm{dU}$,maka dapat disimpulkan bahwa tidak terdapat autokorelasi karena DW > DU dan DL.

Uji Multikolonieritas Model regresi yang baik seharusnya tidak terjadi korelasi di antara variabel independen (Ghozali, 2016:103). Untuk mendeteksi ada atau tidaknya 
multikolonieritas di dalam model regresi dapat dilihat dengan nilai Tolerance (TOL) dan Variance Inflation Factor (VIF).

\section{Tabel 3. Hasil Uji Multikolonieritas}

\begin{tabular}{crc}
\hline \multirow{2}{*}{ Determinan } & \multicolumn{2}{c}{ Collinearity Statistics } \\
& Tolerance & VIF \\
\hline ROE & .972 & 1.029 \\
PER & .999 & 1.001 \\
TATO & .972 & 1.029 \\
\hline
\end{tabular}

Berdasarkan data output SPSS diatas, dapat diketahui bahwa hasil pengujian nilai Tolerance dari variabel ROE sebesar $0.972>0.10$ dan nilai VIF sebesar $1.029<10.00$, sehingga dengan demikian dapat dinyatakan bahwa data hasil pengujian tidak terjadi multikolonieritas. Kemudian nilai Tolerance dari variabel PER sebesar $0.999>0.10$ dan nilai VIF sebesar $1.001<10.00$, sehingga dengan demikian dapat dinyatakan bahwa data hasil pengujian tidak terjadi multikolonieritas. Selanjutnya nilai Tolerance dari variabel TATO sebesar $0.972>$ 0.10 dan nilai VIF sebesar $1.029<10.00$, sehingga dengan demikian dapat dinyatakan bahwa data hasil pengujian tidak terjadi multikolonieritas.

Uji Heterokedastisitas bertujuan menguji apakah dalam model regresi terjadi ketidaksamaan varian dari residual satu pengamatan ke pengamatan lain. Jika varian dari residual dari satu pengamatan ke pengamatan yang lain tetap, maka disebut Homokedastisitas. Dan jika varian berbeda disebut Heterokedastisitas. Model regresi yang baik adalah tidak terjadi heteroskedastisitas (Ghozali, 2016:134).

Tabel 4. Hasil Uji Heterokedastisitas

\begin{tabular}{crr}
\hline Model & $\mathrm{t}$ & \multicolumn{1}{l}{ Sig. } \\
\hline (Constant) & 1.025 & .312 \\
ROE & .442 & .661 \\
PER & -.059 & .953 \\
TATO & -1.313 & .197 \\
\hline
\end{tabular}

Berdasarkan data output SPSS diatas, hasil pengujian uji heterokedastisitas menunjukkan bahwa nilai p-value pada ROE sebesar $0.661>$ 0.05; PER sebesar $0.953>0.05$ dan TATO sebesar $0.197>0.05$, sehingga hasil tersebut mengindikasikan bahwa tidak terjadi heterokedastisitas.

Uji Linearitas digunakan untuk mengetahui apakah dua variabel mempunyai hubungan yang linear atau tidak secara signifikan (Ghozali, 2016:105). Kriteria dalam uji linearitas adalah dua variabel dikatakan mempunyai hubungan yang linear apabila signifikasi (linearity) $<0,05$.

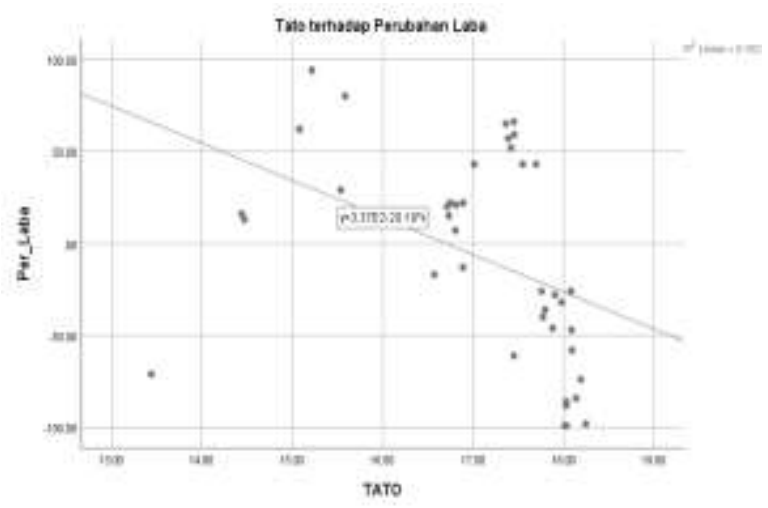
Gambar 1. Linearitas efek TATO pada
Perubahan Laba.

Berdasarkan Scatterplot pada Gambar 1. diatas, menunjukkan bahwa adanya hubungan linear antara Tato terhadap perubahan laba dengan nilai linearitas 0.182 .

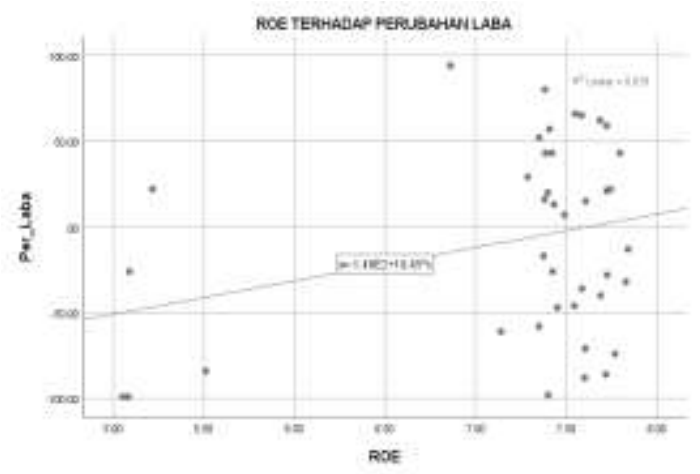

\section{Gambar 2. Linearitas efek ROE pada Perubahan Laba.}

Scatterplot pada Gambar 2. menunjukkan bahwa adanya hubungan linear antara ROE terhadap perubahan laba dengan nilai linearitas 0.078 . 


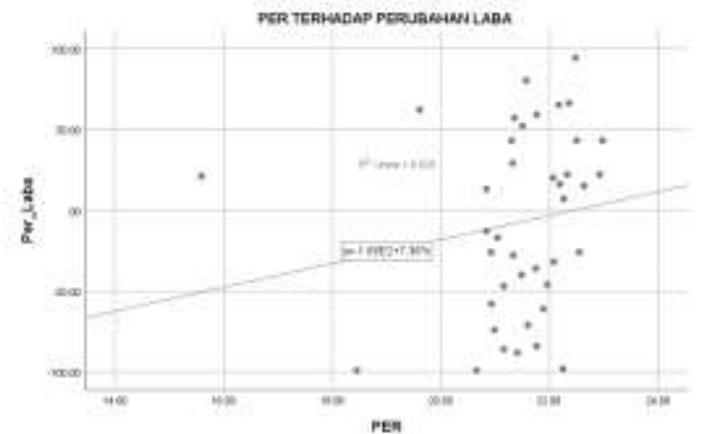

\section{Gambar 3. Linearitas efek PER pada} Perubahan Laba.

Hasil Scatterplot pada Gambar 3. menunjukkan bahwa adanya hubungan linear antara PER terhadap perubahan laba dengan nilai linearitas 0.028 .

\section{Analisis Statistik Deskriptif}

Analisis statistik deskriptif adalah statistik yang memberikan gambaran atau mendeskripsikan data menjadi sebuah informasi yang lebih jelas dan mudah dipahami (Ghozali, 2016:19).

Tabel 5. Statistik Deskriptif

\begin{tabular}{crr}
\hline Variable & \multicolumn{1}{c}{ Mean } & \multicolumn{1}{c}{ Std. Deviation } \\
\hline Per_Laba & -7.5000 & 56.29228 \\
ROE & 7.2295 & .80746 \\
PER & 21.4477 & 1.28258 \\
TATO & 17.0676 & 1.18944 \\
\hline
\end{tabular}

Berdasarkan hasil statistic deskriptif, dapat dilihat bahwa dalam penelitian ini sampel $(\mathrm{N})$ yang digunakan sebanyak 40 data, pada perincian data analisis statistik deskriptif masing-masing variabel independen dan variabel dependen, nilai rata-rata (mean) dan standar deviasi.

Pada variabel perubahan laba nilai rata-rata (mean) sebesar -7.5000 , dengan nilai standar deviasi sebesar 56.29228. Nilai rata-rata (mean) yang lebih kecil ini menunjukkan bahwa hasil deskriptif variabel yang digunakan adalah kurang baik.

Nilai rata-rata (mean) variabel ROE sebesar 7.2295, dengan nilai standar deviasi sebesar 0.80746. Maka nilai rata-rata (mean) yang lebih besar ini dapat dinyatakan bahwa terjadi peningkatan nilai, sehingga hasil deskriptif variabel yang digunakan adalah baik.
Nilai rata-rata (mean) variabel PER sebesar 21.4477, dengan nilai standar deviasi sebesar 1.28258. Hal ini dapat dinyatakan bahwa terjadi peningkatan fluktuasi nilai yang disebabkan besarnya nilai rata-rata dibandingkan nilai standar deviasinya.

Nilai rata-rata (mean) variabel TATO sebesar 17.0676, dengan nilai standar deviasi sebesar 1.18944. Maka nilai rata-rata (mean) yang lebih besar ini dapat dinyatakan bahwa terjadi peningkatan nilai, sehingga hasil deskriptif variabel yang digunakan adalah baik.

\section{Uji Regresi Linear Berganda}

Penentuan terdapat ataupun tidaknya pengaruh yang positif signifikan ataupun sebaliknya, dapat dilihat pada nilai t-hitung dan p-value, untuk itu hasilnya dapat ditunjukkan sebaagai berikut:

Tabel 6. Hasil Uji Regresi Linear Berganda

\begin{tabular}{crrr}
\hline & \multicolumn{3}{c}{ Unstandardized } \\
Model & \multicolumn{3}{c}{ Coefficients } \\
& \multicolumn{3}{c}{$\mathrm{t}$} \\
\cline { 2 - 3 } & \multicolumn{3}{c}{ Std. } \\
& \multicolumn{3}{c}{ Error } \\
\hline (Constant) & 42.952 & 198.196 & .217 \\
ROE & 14.665 & 10.162 & 1.443 \\
PER & 7.605 & 6.310 & 1.205 \\
TATO & -18.724 & 6.900 & - \\
& & & 2.714 \\
\hline
\end{tabular}

Berikut hasil dari pengujian yang telah dilakukan:

$\mathrm{Y}_{\text {(Per.Laba) }}=42.952_{\text {(Kons. })}+14.665_{(\mathrm{ROE})}+$ $7.605_{(\mathrm{PER})}-18.724_{(\mathrm{TATO})}+198.196_{(\mathrm{e})}$

Dari persamaan regresi tersebut, dapat dijelaskan sebagai berikut:

1) Angka konstanta sebesar 42.952 menyatakan jika return on equity $\left(\mathrm{X}_{1}\right)$, price earning ratio $\left(\mathrm{X}_{2}\right)$ dan total asset turnover $\left(\mathrm{X}_{3}\right)$ nilainya 0 , maka perubahan laba (Y) nilainya sebesar 42.952 .

2) Koefisien ROE sebesar 14.665 menyatakan bahwa setiap penambahan $1 \%$ ROE, maka akan meningkatkan perubahan laba sebesar 14.665 pada saat variabel lainnya tidak berubah (konstan).

3) Koefisien PER sebesar 7.605 menyatakan bahwa setiap penambahan $1 \%$ PER, maka akan meningkatkan perubahan laba sebesar 7.605 pada saat variabel lainnya tidak berubah (konstan). 
4) Koefisien TATO sebesar -18.724 menyatakan bahwa setiap penambahan $1 \%$ TATO, maka akan menurunkan perubahan laba sebesar 18.724 pada saat variabel lainnya tidak berubah (konstan).

\section{Uji Kelayakan Model} Uji Fisher Test

Tabel 7. Hasil Uji Fisher Test

\begin{tabular}{lll}
\hline Model & F & Sig. \\
\hline Regression & 4.140 & $.013^{\mathrm{b}}$ \\
\hline
\end{tabular}

Nilai F-tabel berpedoman pada Ftabel $=(0.05,2,37)$, sehingga diperoleh nilai $\mathrm{F}$ tabel dalam penelitian ini yaitu 3.25. Maka disimpulkan bahwa nilai F-hitung lebih besar daripada F-tabel $(4.140>3.25)$ dan nilai signifikansinya lebih kecil dari 0.05 (0.013 < 0.05), maka model yang disusun memenuhi kriteria kelayakan model.

\section{Uji Student test}

Tabel 8. Hasil Uji Student test

\begin{tabular}{ccc}
\hline Model & $\mathrm{t}$ & Sig. \\
\hline ROE & 1.443 & .158 \\
PER & 1.205 & .236 \\
TATO & -2.714 & .010 \\
\hline
\end{tabular}

Nilai t-tabel berpedoman pada nilai $\mathrm{df}=(\mathrm{n}-\mathrm{k}-1)$ sehingga diperoleh nilai df sebesar $37=(40-2-1)$. Nilai t-tabel dilakukan dengan melihat tabel $t$, sehingga memperoleh nilai t-tabel sebesar 2.026. Berdasarkan hasil penelitian, maka hanya TATO yang signifikan terhadap perubahan laba.

\section{Uji Koefisien Determinasi $\left(\mathbf{R}^{2}\right)$} Tabel 9. Hasil Uji Koefisien Determinasi $\left(\mathbf{R}^{2}\right)$

\begin{tabular}{crr}
\hline Model & R & \multicolumn{2}{c}{ R Square } \\
\hline Regression & $.506^{\mathrm{a}}$ & .257 \\
\hline
\end{tabular}

Berdasarkan output SPSS pada tabel 10. di atas, menunjukkan bahwa nilai uji koefisien determinasi $\left(\mathrm{R}^{2}\right)$ sebesar 0.257 yang berarti menunjukkan pengaruh antar variabel independen yaitu ROE, PER dan TATO terhadap variabel dependen yaitu perubahan laba sebesar $25.75 \%$. Hal ini mengartikan bahwa perubahan laba $(\mathrm{Y})$ dapat dipengaruhi oleh ROE $\left(\mathrm{X}_{1}\right)$, PER $\left(\mathrm{X}_{2}\right)$ dan TATO $\left(\mathrm{X}_{3}\right)$, sedangkan sisanya $74.25 \%$ dipengaruhi oleh faktor-faktor lain yang tidak dijelaskan dalam penelitian ini.

\section{1) Return On Equity (ROE) Efek pada Perubahan Laba}

Hasil uji-t variabel ROE terhadap perubahan laba diperoleh nilai t-hitung 1.443 dengan nilai signifikan 0.158. Nilai signifikan lebih besar dari p-value 0.05 atau $0.158>0.05$, maka $\mathrm{H}_{1}$ ditolak dan $\mathrm{H}_{0}$ diterima. Variabel ROE mempunyai t-hitung yaitu 5.348 dengan $\mathrm{t}$-tabel 2.026, sehingga nilai t-hitung < t-tabel $(1.443<$ 2.026) dan menyatakan bahwa ROE tidak memberikan kontribusi terhadap perubahan laba. Jadi dapat disimpulkan bahwa ROE tidak berpengaruh terhadap perubahan laba.

Hasil penelitian ini sesuai dengan penelitian yang dilakukan Cyndia Pangerapan, dkk., (2017), yang menemukan bahwa Return On Equity tidak berpengaruh dalam memprediksi perubahan laba di masa yang akan datang. Temuan dari studi ini menolak hasil penelitian terdahulu yang membuktikan bahwa ROE berpengaruh negatif dan signifikan terhadap perubahan laba (Ghazali dan Martunis 2013:25). ROE berpengaruh positif dan signifikan terhadap perubahan laba (Suprihatmi dan Wahyudin 2003).

\section{2) Efek Price Earning Ratio (PER) pada Perubahan Laba}

Uji $t$ variabel DPS terhadap harga saham diperoleh nilai t-hitung 1.205 dengan nilai signifikan 0.236. Nilai signifikan lebih besar dari p-value 0.05 atau $0.236>0.05$, maka $\mathrm{H}_{1}$ ditolak dan $\mathrm{H}_{0}$ diterima. Variabel PER mempunyai t-hitung yaitu 1.205 dengan $\mathrm{t}$-tabel 2.026, sehingga nilai t-hitung < t-tabel $(1.205<$ 2.026) dan menyatakan bahwa PER tidak memiliki kontribusi terhadap harga saham. Jadi dapat disimpulkan bahwa PER tidak berpengaruh terhadap perubahan laba.

Hasil penelitian ini sesuai dengan penelitian yang dilakukan Cyndia Pangerapan, dkk., (2017); Nur Amalina, dkk., (2014). bahwa Price Earning Ratio tidak berpengaruh dalam memprediksi perubahan laba di masa yang akan datang. Hasil penelitian ini menolak temuan Sri Lestari, (2014) bahwa PER berpengaruh positif dan signifikan dalam memprediksi perubahan laba di masa yang akan datang. 


\section{3) Total Assets Turn Over (TATO) efek pada Perubahan Laba}

Uji t variabel TATO terhadap perubahan laba diperoleh nilai t-hitung -2.714 dengan nilai signifikan 0.010. Nilai signifikan lebih kecil dari $p$-value 0.05 atau $0.010<0.05$, maka $\mathrm{H}_{1}$ diterima dan $\mathrm{H}_{0}$ ditolak. Variabel TATO mempunyai t-hitung yaitu -2.714 dengan t-tabel 2.026, sehingga nilai t-hitung $<\mathrm{t}$-tabel $(-2.714$ $<2.026)$ dan menyatakan bahwa TATO memiliki kontribusi terhadap perubahan Laba. Jadi dapat disimpulkan bahwa TATO memiliki pengaruh negarif dan signifikan terhadap perubahan laba.

Hasil penelitian ini mendukung penelitian yang dilakukan Cyndia Pangerapan, dkk., (2017), bahwa Perputaran Total Aktiva tidak berpengaruh dalam memprediksi perubahan laba di masa yang akan datang. Mendukung sebahagian temuan Sari, (2007) bahwa TATO berpengaruh negatif dan tidak signifikan terhadap perubahan laba. Studi ini menolak temuan Syamsuddin dan Primayuta, (2009) bahwa TATO berpengaruh positif dan signifikan terhadap perubahan laba.

\section{KESIMPULAN DAN SARAN}

Return On Equity tidak berpengaruh dalam memprediksi perubahan laba. Hal ini dapat dilihat dari hasil pengujian t-statistik yang diperoleh nilai t-hitung sebesar 1.443 dan nilai signifikan sebesar 0.158. Sesui dengan hasil tersebut maka dapat dinyatakan ROE yang tinggi dalam pelaksanaanya tidak mampu memprediksi laba dimasa mendatang.

Price Earning Ratio tidak berpengaruh dalam memprediksi perubahan laba. Hal ini dapat dilihat dari hasil pengujian t-statistik efek PER terhadap harga saham yang diperoleh nilai thitung sebesar 1.205 dan nilai signifikan sebesar 0.236. Berdasarkan pembuktian statistic tersebut, maka dapat dijelaskan jika PER yang tinggi dalam pelaksanaanya tidak mampu memprediksi laba dimasa mendatang.

Total Assets Turn Over berpengaruh negatif dan signifikan dalam memprediksi perubahan laba (t-hitung yaitu -2.714 dengan t-tabel 2.026). Bahwa TATO yang rendah terbukti dapat memprediksi perubahan laba dimasa mendatang

Kontribusi terpenting dari ketiga variabel pengamatan, yaitu return on equity, price earning ratio, total asset turnover, menempatkan Total Assets Turn Over sebagai contributor terpenting dalam memprediksi perubahan laba dimasa mendatang dengan total nilai kontribusi sebesar 50,6\%.

Studi merekomendasikan pada peneliti selanjutnya untuk menambah jangka waktu pengamatan yang lebih panjang, karena semakin lama waktu pengamatan maka semakin besar kesempatan untuk melakukan penelitian yang akurat.

Diperoleh hasil bahwa return on equity dan price earning ratio tidak dapat berkontribusi dalam memprediksi perubahan laba dimasa mendatang, sehingga peneliti selanjutnya diharapkan mempertimbangkan menggunakan variabel return on equity dan price earning ratio.

Hasil penelitian ini masih banyak memiliki keterbatasan, sehingga sangat diharapkan untuk peneliti selanjutnya menambahkan variabelvariabel lain yang dapat mempengaruhi perubahan laba agar memperluas area penelitian.

\section{REFERENSI}

Aderina K Harahap, dan Ni Ketut Yayu Safitri. (2018). Analisis Manfaat Rasio Keuangan Dalam Memprediksi Perubahan Laba Pada Perusahaan Manufaktur Sub Sektor Otomotif Yang Terdaftar di Bursa Efek Indonesi (BEI) di Indonesia. Jurnal Riset Akuntansi dan Manjemen, Vol. 7, No. 2, Desember 2018.

Alamsyah. (2006). Analisis Rasio Keuangan dan Prediksi Kesulitan Keuangan (Financial Distress) pada Koperasi di Kabupaten Bima, Jurnal Riset Akuntansi, Vol. 5, No. 2.

Amalina. (2013). Analisis Rasio Keuangan dalam Memprediksi Perubahan Laba (Studi Empiris: Perusahaan Manufaktur yang Terdaftar pada Bursa Efek Indonesia Periode Tahun 2008 2011. Universitas Diponegoro.

Ang, Robert. (1997). Buku Pintar Pasar Modal Indonesia. Jakarta: Mediasoft Indonesia.

Chariri, Anis dan Imam Ghozali. (2013). Teori Akuntansi. Edisi Delapan. Jakarta: Salemba Empat.

Chyntia Sirila Manurung dan Evelin R.R. Silalahi. (2016). Analisis Rasio Keuangan dalam Memprediksi Perubahan Laba pada Perusahaan 
Manufaktur Yang Terdaftar di Bursa Efek Indonesia (BEI). JRAK - Vol. 2 No. 1, Maret 2016.

Cyndia Pangerapan, David Saerang, dan Hence Wokas. (2017). Analisis Rasio Keuangan dalam Memprediksi Perubahan Laba di Masa Yang Akan Datang pada PT. Bank Rakyat Indonesia (Persero) Tbk. Jurnal Riset Akuntansi Going Concern 12(2), 2017, 470-479.

Engelwati Gani dan Almitra Indira. (2011). Analisa Rasio Keuangan Untuk Memprediksi Perubahan Laba Pada Perusahaan Telekomunikasi Indonesia. Binus Business Review Vol. 2 No. 2 November 2011: 883-898.

Fahmi, Irham. (2012). Analisis Laporan Keuangan. Bandung: Alfabeta.

Ghazali Syamni dan Martunis. (2013). Pengaruh OPM, ROE, dan ROA Terhadap Perubahan Laba pada Perusahaan Telekomunikasi di Bursa Efek Indonesia. Jurnal Kebangsaan, Volume 2 No.4.

Ghozali, Imam. (2016). Aplikasi Analisis Multivariate dengan Program IBM SPSS Semarang: Universitas Diponegoro.

Hakim, Rizal Nur. (2013). Faktor-faktor yang Berpengaruh terhadap Perubahan Laba Bank. Jurnal Univesitas Dian Nuswantoro.

Hanafi, Mamduh M dan Abdul Halim. (2003). Analisis Laporan Keuangan UPP AMP YKPN, Yogyakarta.

Harahap, Sofyan Safri. (2010). Analisis Krisis Atas Laporan Keuangan. Jakarta: Raja Grafindo Persada.

Harris, M. I., Sjahruddin, H., \& Themba, O. S. (2020). Kontribusi Rasio Aktivitas dan Ukuran Perusahaan pada Rentabilitas PT. Telekomunikasi Indonesia (Persero), Tbk. Jurnal SEKURITAS (Saham, Ekonomi, Keuangan dan Investasi), 3(3), 219229.
Henry, Simamora. (2000). Akuntansi Basis Pengambilan Keputusan dan Bisnis. Salemba Empat, Jakarta.

Ikatan Akuntansi Indonesia (IAI). (2012). Standar Akuntansi Keuangan. Jakarta (ID): Salemba Empat.

Kasmir. (2010). Pengantar Manajemen Keuangan. Edisi Pertama. Cetakan Kedua. Jakarta: Kencana Prenada Media Group.

Kieso, Donald E, Weygant, Jerry J dan Warfield, Terry D. (2008). Akuntansi Intermediate. Jilid 1. Ahli Bahasa: Emil Salim. Edisi Keduabelas. Jakarta; Erlangga.

Lestari, Sri. (2014). Analisis Pengaruh Rasio Keuangan dalam Memprediksi Perubahan Laba pada Perusahaan BUMN yang Terdaftar di BEI Periode 2007-2011. Karya Ilmiah. Surakarta.

Lorenza, D., Kadir, M. A., \& Sjahruddin, H. (2020). Pengaruh Struktur Modal Dan Ukuran Perusahaan Terhadap Profitabilitas Pada Perusahaan Otomotif Yang Terdaftar Di BEI. Jurnal Ekonomi Manajemen, 6(1), 13-20.

Luluk Muhimatul Ifada dan Tiara Puspitasari. (2016). Analisis Pengaruh Rasio Keuangan Terhadap Perubahan Laba. Jurnal Akuntansi \& Auditing Volume 13/No. 1 Tahun 2016: 97-108.

Mabue Kumbirai and Robert Webb. (2010). A

Financial Ratio Analysis of Commercial Bank Performance in South Africa.

Martono, dan Harjito D. (2010). Manajemen Keuangan. Yogyakarta: Ekonisia.

Nindhika Paramawardhani, Tatang Ary Gumanti, dan Novi Puspitasari. (2014). Rasio Keuangan Dan Perubahan Laba Perusahaan Agroindustri Di Bursa Efek Indonesia. Jurnal Pasca Sarjana Universitas Jember.

Riyanto, Bambang, (2013). Dasar-Dasar Pembelanjaan Perusahaan. Yogyakarta: BEP. 
Sari, Yuni Nurmala. (2007). Pengaruh Current Ratio, Debt To Equity Ratio, Dan Total Assets Turn Over Terhadap Perubahan Laba Pada Perusahaan Manufaktur Di Bursa Efek Jakarta, Skripsi, Fakultas Ekonomi Universitas Negeri, Semarang.

Sofyan Syafri Harahap. (2012). Teori Akuntansi. Penerbit Erlangga Jakarta.

Sugiyono. (2016). Metode Penelitian Bisnis. Alfabeta. Bandung.

Sugiyono. (2017). Statistik Untuk Penelitian. Cetakan Kedua Puluh Tujuh, Penerbit: Alfabeta, Bandung.

Suprihatmi dan Wahyudin. (2003). Pengaruh Rasio Keuangan Terhadap Kemampuan Memprediksi Perubahan Laba Pada Perusahaan Manufaktur Yang Terdaftar Di Bursa Efek Indinesia (BEI). Jurnal Manajemen Daya Saing. Vol. 4, No. 2, Juni 2013 hal. 9-21.

Suwarno, A. E. (2004). Manfaat Informasi Rasio Keuangan Dalam Memprediksi Perubahan Laba: Studi Empiris Terhadap Perusahaan Manufaktur Go Publik di Bursa Efek Jakarta. Jurnal Akuntansi dan Keuangan, Vol. 3, No. 2. Syamsudin, dan Primayuta, Ceky. (2009). Rasio Keuangan dan Prediksi Perubahan Laba Perusahaan Manufaktur. Jurnal Manajemen dan Bisnis. Vol 13, No. 1: 61-69, Juni 2009.

Teguh. (2011). Price Earnings Ratio dan Price to Book Value. http://teguhidx. blogspot.com, 14 Februari 2011.

Van Horne, James C. Dan John M. Wachowicz, Jr. (2010). Prinsip-Prinsip Manajemen Keuangan, Buku Satu, Edisi Kedua Belas, Alih Bahasa Oleh Dewi Fitriasari Dan Denny ArnosoKwary, Salemba Empat, Jakarta.

Victorson Taruh. (2012). Analisis Rasio Keuangan Dalam Memprediksi Pertumbuhan Laba Pada Perusahaan Manufaktur Di BEI. Jurnal Riset Prodik Magister Manajemen Unismu Surakarta.
Wild, John J. dan K.R. Subramanyam. (2015). Analisis Laporan Keuangan, Salemba Empat, Jakarta.

Winda Kurniawati. (2016). Prediksi Laba di Masa Yang Akan Datang Dengan Rasio Keuangan pada Perusahaan Manufaktur Yang Terdaftar di Bursa Efek Indonesia Periode 2010-2014. JPSB Vol.4 No.1. 